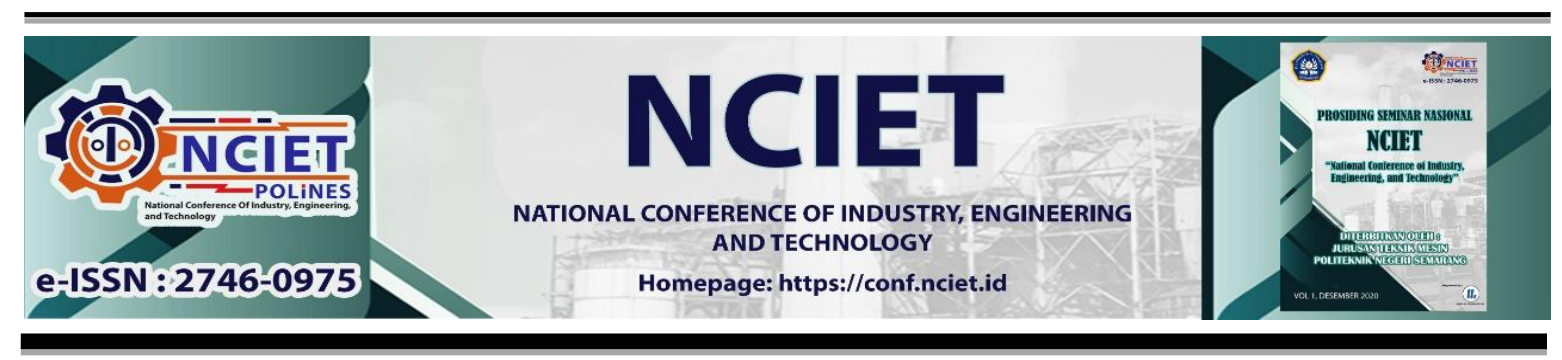

Prosiding Seminar Nasional NCIET Vol.1 (2020) B218-B226

$1^{\text {st }}$ National Conference of Industry, Engineering and Technology 2020,

Semarang, Indonesia.

\title{
VARIASI PENGGUNAAN BATUBARA TERHADAP HEAT RATE PLTU SUBKRITIKAL DI PLTU KAPASITAS 600 MW
}

\author{
M. Faris Robbani Disastra*, Ika Yuliyani \\ Jurusan Teknik Konversi Energi, Politeknik Negeri Bandung \\ Jl. Gegerkalong Hilir, Ds. Ciwaruga Kecamatan Parongpong Kabupaten Bandung Barat, \\ 40012 \\ *E-mail: disastrafaris@gmail.com
}

\begin{abstract}
Abstrak
Sistem Pembangkit Listrik Tenaga Uap (PLTU) berbahan bakar batubara merupakan salah satu pembangkit yang saat ini banyak digunakan dan dapat menghasilkan listrik dengan kapasitas yang cukup besar, dan mengkonsumsi batu bara dalam jumlah yang cukup besar. Kemampuan dari PLTU tersebut dalam mengkonsumsi batubara, salah satunya dapat dilihat dari nilai heat rate nya. Heat rate adalah besar energi bahan bakar atau panas yang digunakan pada suatu pembangkit PLTU untuk menghasilkan besarnya energi listrik per- kWHnya. Penggunaan batubara pada suatu pembangkit pada umumnya memiliki nilai kalor yang bervariasi, hal ini pada umumnya terjadi karena suplai batubara berasal dari beberapat tempat penambangan, hal ini tentunya akan berpengaruh terhadap konsumsi bahan bakar batu bara dan tentunya akan mempengaruhi nilai heat rate. Hasil penelitian pada PLTU sub critical kapasitas $600 \mathrm{MW}$, diketahui bahwa penggunaan jenis batu bara low rank dengan variasi nilai kalori antara 4713,65 $\mathrm{kCal} / \mathrm{kg}$ sampai $5109,80 \mathrm{kCal} / \mathrm{kg}$. Berdasarkan perhitungan dan analisa diperoleh nilai heat rate yang bervariasi dengan nilai antara $2419,30 \mathrm{kCal} / \mathrm{kWh}$ sampai $2533,23 \mathrm{kCal} / \mathrm{kWh}$, yang artinya variasi nilai kalori batubara berpengaruh terhadap konsumsi batubara dalam menghasilkan listrik per kWh nya. Selain itu diketahui juga rata-rata nilai heat rate pada penggunaan variasi jenis batubara dengan nilai kalori ini menghasilkan nilai heat rate yang masih berada dengan nilai target RKAP nya, yaitu sebesar sebesar $2465,27 \mathrm{kCal} / \mathrm{kWh}$. Hal ini menunjukkan bahwa ada pengaruh penggunaan variasi jenis batu bara dengan kalori berbeda terhadap nilai heat ratenya.
\end{abstract}

Kata kunci: batubara; heatrate; PLTU; nilai kalori.

\section{PENDAHULUAN}

Listrik merupakan kebutuhan utama dalam kehidupan manusia. Saat ini listrik tidak hanya terdapat di kota besar saja melainkan sudah masuk ke desa-desa. Banyak industri besar yang menggunakan listrik sebagai penyuplai utama. Dalam kehidupan sehari-hari pun manusia menggunakan listrik untuk berbagai keperluan, diantaaranya sebagai penerangan, untuk menghidupakan peralatan rumah tangga, dan masih banyak lainnya. Maka dari itu di Indonesia banyak sekali pembangkit listrik dengan berbagai tenaga. Salah 
satunya adalah Pembangkit Listrik Tenaga Uap (PLTU). PLTU merupakan pembangkit yang mengandalkan energi kinetik dari uap untuk menghasilkan energi listrik. Dalam pengoperasian PLTU dibutuhkan bahan bakar. Salah satu bahan bakar yang banyak digunakan yaitu batubara.

Batubara terdapat beberapa jenis menurut standar ASTM (American Society of Testing and Materials), diantaranya gambut, lignit, sub-bituminus, bituminus, dan antrasit. Penggolongan tersebut berdasarkan kandungan air (moisture), zat terbang (volatile matter), presentase abu atau kadar abunya, dan karbon tetapnya (fixed carbon) serta nailai kalor dari batubara itu sendiri. Berdasarkan standar batubara yang memiliki kualitas tinggi adalah antrasit sedangkan yang kurang baik ada gambut dan lignit.

Kualitas dari setiap jenis batubara akan mempengaruhi kinerja dari sebuah PLTU. Dimana Kinerja dari PLTU dapat ditentukan dengan mencari efisiensi dan heat rate atau tara kalor yang dihasilkan. Efisiensi merupakan perbandingan antara keluaran dengan masukan atau hasil antara keuntungan dengan sumber-sumber yang dipergunakan. Heat rate didefinisikan sebagai perbandingan jumlah energi yang digunakan terhadap daya listrik yang terpakai pada tiap jamnya.

Adanya variasi penggunaan jenis batubara pada beberapa pembangkit perlu diketahui untuk dapat pengidentifikan salah satu kinerjanya, yaitu dengan menghitung heat rate dari suatu pembangkit listrik tenaga uap. Sehingga dapat diketahui informasi terkait pengaruh dari penggunaan jenis batubara yang berbeda tersebut.

\section{METODE PENELITIAN}

Listrik merupakan kebutuhan utama dalam kehidupan manusia. Saat ini listrik tidak hanya Dalam melakukan penelitian, penulis mengambil tempat di PLTU Subkritikal berkapasitas $600 \mathrm{MW}$.

PLTU ini termasuk pembangkit listrik terbesar di Indonesia yang memasok listrik dengan total kapasitas terpasang sebesar 4025 MW yang merupakan penyokong utama kebutuhan listrik bagi seluruh aktivitas industri, pembangunan, pendidikan, penigkatan ilmu pengetahuan dan teknologi khususnya di Jawa Barat. Pembangkit ini menggunakan batubara sebagi bahan bakar utama, bahan bakar minyak diesel/HSD sebagai penyalaan awal dan Main Oil Fuel sebagai bahan bakar cadangan pada saat keadaan darurat.

Adapun proses pembangkitan listrik di PLTU sebagai berikut : 
Pembangkit listrik tenaga uap (PLTU) merupakan industri pembangkit yang mengkonversi energi kimia dalam bahan bakar menjadi energi listrik. Konversi energi dalam PLTU dapat dilihat pada skema berikut ini:

\begin{tabular}{|c|c|c|}
\hline Energi kimia \\
\hline $\begin{array}{c}\text { Tangki } \\
\text { Bahan Bakar }\end{array}$
\end{tabular}$\rightarrow$\begin{tabular}{|c|c|}
\hline Energi panas \\
\hline Furnace \\
\hline
\end{tabular} \begin{tabular}{c} 
Energi mekanik \\
Turbin \\
Generator \\
\hline
\end{tabular}

Energi kimia yang disimpan dalam tangki bahan bakar kemudian dimasukan ke dalam furnace untuk dibakar dengan udara sehingga menghasilkan energi panas. Energi panas yang dihasilkan kemudian diterima oleh air sehingga air tersebut berubah fasa menjadi uap. Uap tersebut akan mendorong sudu-sudu turbin sehingga poros turbin ikut berputar. Poros generator akan ikut berputar jika poros turbin berputar sehingga akan menghasilkan energi listrik.

Adapun tahapan penelitian yang digunakan:

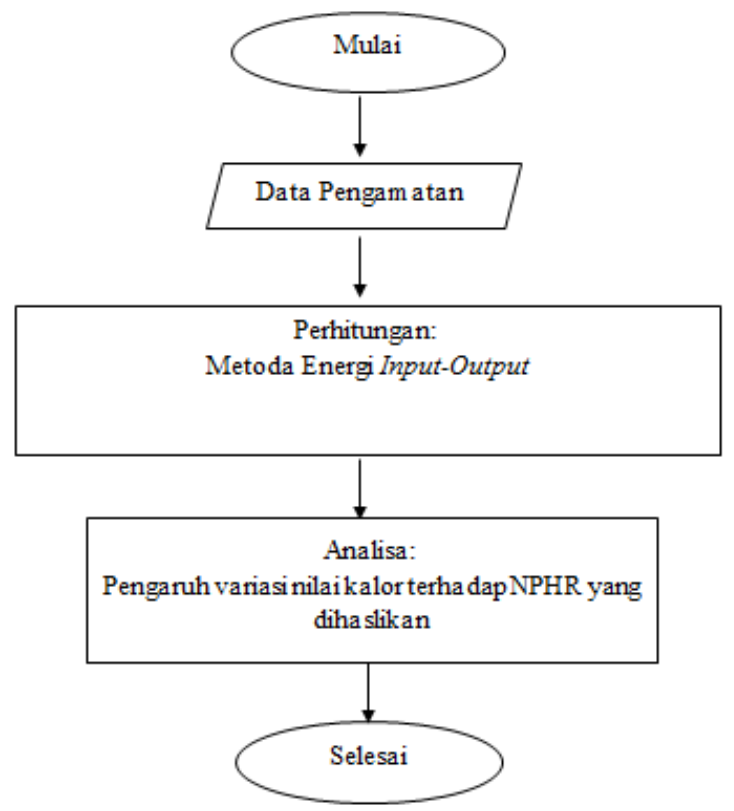

Gambar 1. Diagram Alir Penelitian

Berdasarkan diagram alir tersebut, penulis dapat menjelakan bagaimana tahapan dalam menghitung nilai heat rate. Langkah-langkah yang dilakukan antar lain:

1. Data Pengamatan 
Tahapan pertama yaitu mengumpulkan data-data yang dibutuhkan untuk menemukan nilai dari heat rate sistem PLTU dan digunakan supaya tujuan dari penelitian tugas akhir dapat tercapai. Data yang didapatkan berasal dari jurnal yang melakukan penelitian di PLTU tersebut. Adapun data yang dibutuhkan diantaranya:

Tabel 1. Data yang dibutuhkan

\begin{tabular}{|l|l|}
\hline \multicolumn{1}{|c|}{ Parameter } & \multicolumn{1}{c|}{ Satuan } \\
\hline Output Generator Power & $\mathrm{MW}$ \\
\hline Fuel Flow & $\mathrm{Ton} / \mathrm{h}$ \\
\hline Nilai Kalor & $\mathrm{kCal} / \mathrm{kg}$ \\
\hline
\end{tabular}

\section{Perhitungan}

Setelah data-data yang dibutuhkan terkumpul, tahapan selanjutnya adalah melakukan perhitungan. Perhitungan yang dipakai yaitu metoda input-ouput, dimana melakukan perbandingan antara energi input (energi bahan bakar/batubara) dan energi output (daya generator). Metoda ini dilakukan dengan menghitung NPHR (Net Plant Heat Rate), dimana pada energi output daya generator yang dihasilkan dikurangi dengan pemakaian sendiri. Adapun rumus yang dipakai :

$$
N P H R=\frac{\dot{m} \times G C V}{\text { Net } \cdot \text { Load }}
$$

Keterangan :

NPHR = Net Plant Heat Rate $(\mathrm{kCal} / \mathrm{kWh})$

$\dot{\mathrm{m}}=$ Fuel Flow (ton/h)

$\mathrm{GCV}=$ Nilai kalori batubara $(\mathrm{kCal} / \mathrm{kg})$

Net Load = Daya Netto yang Generator (MW)

3. Analisis

Selanjutnya melakukan analisis dari perhitungan yang sudah dilakukan. Pada tahapan ini penulis membuat grafik hasil dari perhitungan. Analisa dilakukan dengan melihat pengaruh dari variasi nilai kalor dan beban terhadap NPHR, dimana pada setiap harinya nilai kalor dari batubara berbeda. Hal ini mempengaruhi nilai NPHR yang dihasilkan. Maka dari itu analisis dilakukan untuk mengetahui pengaruh dari variasi beban dan nilai kalor terhadap NPHR yang didapatkan jenis batubara yang berbeda tersebut. 


\section{HASIL DAN PEMBAHASAN}

Batubara yang dipakai mempunyai nilai kalo yang bervariasi. Berikut ini merupakan data nilai kalor dari tiap-tiap batubara :

Tabel 2 .Data Nilai Kalor Batubara

\begin{tabular}{|c|c|}
\hline No. & $\begin{array}{c}\text { Nilai Kalor, } \\
\text { kCal/kg }\end{array}$ \\
\hline 1 & 5030.22 \\
\hline 2 & 5108.62 \\
\hline 3 & 5092.63 \\
\hline 4 & 4963.37 \\
\hline 5 & 4770.57 \\
\hline 6 & 4718.09 \\
\hline 7 & 4844.98 \\
\hline 8 & 4886.21 \\
\hline 9 & 4973.18 \\
\hline 10 & 4991.99 \\
\hline 11 & 5096.38 \\
\hline 12 & 5063.12 \\
\hline 13 & 5105.24 \\
\hline 14 & 5073.97 \\
\hline 15 & 4772.95 \\
\hline 16 & 4750.51 \\
\hline 17 & 4833.76 \\
\hline 18 & 4713.65 \\
\hline 19 & 5061.15 \\
\hline 20 & 5107.52 \\
\hline 21 & 4835.14 \\
\hline 22 & 4894.09 \\
\hline 23 & 4991.77 \\
\hline 24 & 5034.96 \\
\hline 25 & 5094.86 \\
\hline 26 & 5049.96 \\
\hline 27 & 5109.80 \\
\hline 28 & 5027.49 \\
\hline 29 & 5061.38 \\
\hline 30 & 5002.30 \\
\hline 31 & 4831.65 \\
\hline
\end{tabular}


Tabel 3. Hasil Perhitungan Heat Rate

\begin{tabular}{|c|c|c|c|}
\hline $\begin{array}{c}\text { Beban, } \\
\%\end{array}$ & $\begin{array}{c}\text { Nett } \\
\text { Load, } \\
\text { MW }\end{array}$ & GPHR & NPHR \\
\hline $60 \%$ & 364,77 & 2421.70 & 2533.23 \\
\hline $70 \%$ & 422,59 & 2361.86 & 2455.30 \\
\hline $80 \%$ & 481,22 & 2364.99 & 2453.24 \\
\hline $90 \%$ & 541,81 & 2342.05 & 2419.30 \\
\hline
\end{tabular}

Terlihat pada tabel yang ditampilkan bahwa heat rate terendah ada pada kondisi beban $90 \%$ dengan nilai sebesar $2419,30 \mathrm{kCal} / \mathrm{kWh}$. Sedangkan untuk perolehan nilai heat rate terbesar ada pada kondisi beban 60\% dengan hasil yang diperoleh sebesar 2533,23 $\mathrm{kCal} / \mathrm{kWh}$. Apabila nilai heat rate aktual dibandingkan dengan nilai standar sebesar 2495 $\mathrm{kCal} / \mathrm{kWh}$, nilai yang lebih kecil dari nilai standar ada pada beban $70 \%, 80 \%$, dan $90 \%$. Sedangkan pada kondisi beban $60 \%$, nilai heat rate lebih besar dari nilai target standar. Adapun dalam grafik ditampilkan sebagai berikut :

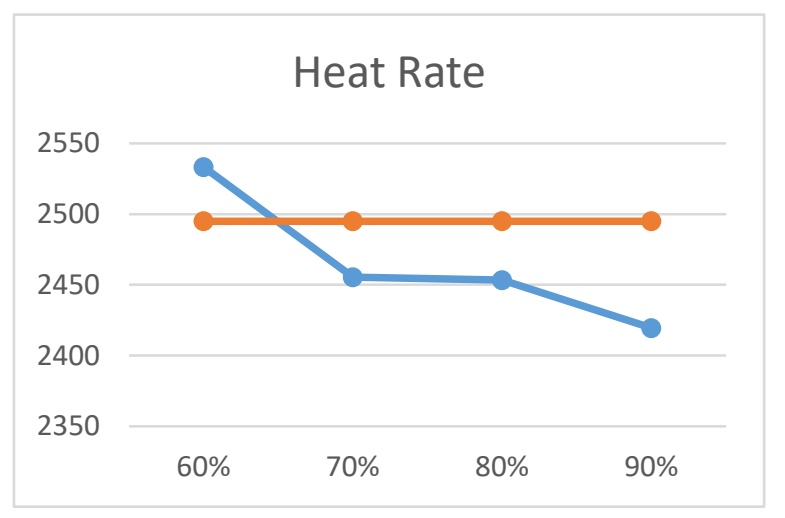

Gambar 2. Grafik Heat Rate terhadap Beban

Namun bila nilai heat rate aktual rata-rata keseluran beban dihitung, nilai yang didapat sebesar 2465,27 kCal/kWh. Nilai heat rate ini lebih kecil dari nili standar yang ada. Adapun pada grafik ditunjukkan semakin besar beban yang diberikan maka nilai heat rate semakin kecil. Hal ini menyatakan bahwa nilai heat rate berbanding terbalik dengan kondisi beban. Berikut ini merupakan grafik perubahan heat rate pada beban $60 \%, 70 \%$, $80 \%$ dan $90 \%$. 
Selain dipengaruhi beban, heat rate juga dipengaruhi oleh nilai kalori batubaranya. Dimana, nilai kalori ini mempengaruhi besarnya nilai energy input. Semakin besar nailai kalori batubara, maka semakin besar pula energi inputnya. Hal ini akan menyebabkan nilai heat rate semakin besar.

Setelah menghitung nilai heat rate, maka akan diketahui juga efisiensinya. Efisiensi adalah perbandingan antar daya yang dibangkitkan dibagi dengan panas yang masuk kedalam sistem. Efisiensi ini dihitung sesuai dengan kondisi beban yang ada, dimana beban yang dipakai yaitu sebesar $60 \%, 70 \%, 80 \%$, dan $90 \%$.

Berikut ini merupakan perhitungan yang dipakai pada nilai heat rate sebesar 2533,23 $\mathrm{kCal} / \mathrm{kWh}$ dengan kondisi beban 60\%. Perhitungan dengan cara 860 dibagi dengan nilai NPHR. Nilai 860 ini merupakan nilai konversi.

$$
\begin{gathered}
\eta=\frac{860}{2533,23} \\
\eta=0,3395 \\
\eta=33,95 \%
\end{gathered}
$$

Setelah dihitung efisiensi, didaptakan nilai dari efisensi selama 1 bulan. Berikut ini merupakan tabel data kompilasi dari setiap beban yang dipasang.

Tabel 4. Data Kompilasi Efisiensi pada tiap Beban

\begin{tabular}{|c|c|}
\hline Beban, \% & Efisiensi, \% \\
\hline $60 \%$ & 33.95 \\
\hline $70 \%$ & 35.03 \\
\hline $80 \%$ & 35.06 \\
\hline $90 \%$ & 35.55 \\
\hline
\end{tabular}

Dari tabel kompilasi terlihat bahwa efisiensi terbesar ada pada beban 90\% dengan nilai efisiensi 35,55\% dan efisiensi terkecil ada pada beban $60 \%$ yaitu sebesar 33,95\%. Sedangkan untuk beban $70 \%$ dan $80 \%$ efisiensi tidak terlalu jauh perbedaanya yaitu sebesar 35,03\% dan 35,06\%. Nilai efisiensi yang dihasilkan diperngaruhi oleh besar NPHR. Dimana ketika NPHR besar maka efisiensi akan kecil, begitupun sebaliknya ketika nilai NPHR kecil maka efisiensi semakin besar. Selain dipengaruhi oleh NPHR, efisiens juga dipengaruhi oleh kondisi beban yang terpasang. Dimana ketika beban kecil maka efisiensi akan kecil dan juga sebaliknya. Hal ini berdasarkan pada prinsip efisiensi yaitu energi 
keluar dibagi dengan energi yang masuk. Ketika energi yang keluar besar maka hasilnya pun akan besar, dan sebaliknya.

Faktor-faktor yang mempengaruhi hasil nilai heat rate dan efisiensi adalah energi input dan energi output. Dimana energi ini merupakan energi dari batubara yang masuk ke dalam boiler, sedangkan energi output merupakan energi listrik yang dihasilkan. Pada energi input kualitas batubara mempengaruhi besarnya nilai yang dihasilkan. Kandungan yang terdapat didalam batubara akan mempengaruhi proses pembakaran yang terjadi didalam furnace pada boiler. Selain itu nilai kalori batubara juga mempengaruhi terhadap energi input yang dihasilkan. Sedangkan pada energi output dipengaruhi oleh pola pembebanan yang dipasang. Pola pembebanan unit yang rendah akan berdampak pada peningkatan nilai heat rate.

\section{KESIMPULAN}

Berdasarkan penelitian Perbandingan Variasi Batubara terhadap Heat Rate PLTU Subkritikal berkapasitas 600 MW yang telah dilakukan dapa disimpulkan bahwa :

1. Nilai heat rate yang dihasilkan pada bulan adalah sebesar $2465,27 \mathrm{kCal} / \mathrm{kWh}$, dimana nilai lebih kecil dari nilai standar yang telah dirancang. Adapun nilai heat rate pada kondisi berbeda sebagai berikut :

a. Pada kondisi beban $60 \%$ nilai heat rate yang dihasilkan sebesar $2533,23 \mathrm{kCal} / \mathrm{kWh}$

b. Pada kondisi beban $70 \%$ nilai heat rate yang dihasilkan sebesar $2455,30 \mathrm{kCal} / \mathrm{kWh}$

c. Pada kondisi beban $80 \%$ nilai heat rate yang dihasilkan sebesar $2455,24 \mathrm{kCal} / \mathrm{kWh}$

d. Pada kondisi beban $90 \%$ nilai heat rate yang dihasilkan sebesar 2419,30 kCal/kWh

2. Heat rate yang dihasilkan dipengaruhi oleh beberapa faktor. Salah satu faktor yang lebih berpengaruh ada kondisi pembebanan yang diberikan. Dimana, ketika kondisi beban besar, maka heat rate yang dihasilkan semakin kecil. Serta sebaliknya. Selain beban, kualitas batubara juga mempengaruhi terhadap heat rate yang dihasilkan.

\section{DAFTAR PUSTAKA}

A.K. Raja, Amit Prakash Srivastava, Manish Dwivedi.(2006). Power Plant Engineering. New Delhi: s.n.

Black\&Veatch. (1996). Power Plant Engineering. Boston: Springer Science+Business Media, Inc.

Francisco, Gilberto. (2012).Thermal Power Plant Performance. London : Springer London Dordrecht Heidelberg

Heat Rate Improvement Reference Manual, EPRI CA: 2014. 3002003457 
Iqbal Dima Naufal dkk.(2019).Analisis Pengaruh Kualitas Batubara terhadap Performa Pembangkit Listrik Tenaga Uap.PNJ.ISSN 2085-2762.01 Desember 2019

Maridjo. (2010). PLTT Pembangkit Listrik Tenaga Thermal. Bandung.Politeknik Negeri Bandung

Moran, Michael J. Howard N.Shapiro . (2004). Termodinamika Teknik Jilid 1. Jakarta . ERLANGGA

Sabiatussa'adah, Yuli. (2018). Analisa Kinerja Boiler Pulverized Coal di PLTU Suralaya Kapasitas 600 MW berdasarkan ASME PTC 4.1. Bandung : Politeknik Negeri Bandung

Tim Heat Rate PLN Puslitbang. (2013). Pengujian Heat Rate dan Efisiensi Pembangkit PLTU Banten 3 Unit 3 Sebelum First Year Inspection. Banten : PT. PLN (Persero) Puslitbang Ketenagalistrikan. 